\title{
Are hospitals our friends? An exploratory study on the role of Facebook in hospital organizations' dialogic communication
}

\section{Gisela Gonçalves}

To cite this article: Gisela Gonçalves (2020): Are hospitals our friends? An exploratory study on the role of Facebook in hospital organizations' dialogic communication, Health Marketing Quarterly, DOI: $10.1080 / 07359683.2020 .1805898$

To link to this article: https://doi.org/10.1080/07359683.2020.1805898

曲 Published online: 24 Aug 2020.

Submit your article to this journal $\pi$

凹 Article views: 11

Q View related articles ¿

View Crossmark data \lceil 


\title{
Are hospitals our friends? An exploratory study on the role of Facebook in hospital organizations' dialogic communication
}

\author{
Gisela Gonçalves \\ Department of Communication, Philosophy and Politics, University of Beira Interior, \\ Covilhã, Portugal
}

\begin{abstract}
Rooted in the dialogic public relations model, the aim of this paper was to analyze the way in which hospital organizations use Facebook to communicate and build relationships with their patients and followers. Using a content analysis of Facebook profiles, there is a reflection on how dialogic principles are applied in the management of Facebook by hospitals in Portugal. Special attention will be paid to communication regarding the Zika virus, which was of public interest at the time the empirical analysis was carried out. The study demonstrates that Portuguese hospitals are present on Facebook but do not use the social network dialogically or to communicate about topical themes of public interest.
\end{abstract}

\section{KEYWORDS}

Dialogic principles; hospital organizations; Facebook; Portugal

\section{Introduction}

On 15 January 2016, Portugal's Directorate-General for Health (DGS) released the first of three statements on a potential outbreak of the Zika virus in Portugal, which was repeated, amplified, and the subject of editorial attention in different media outlets. In these statements, the DGS was concerned with providing information for the Portuguese population, advising travelers with symptoms to contact the Saúde 24 health helpline and pregnant women, the main risk group, to consult the doctor treating them if they had travelled to one of the affected areas. ${ }^{1}$ Although Portugal was a low-risk country, by 28 January there were already 6 confirmed cases, all imported from South America. On 1 February 2016, the World Health Organization (WHO, 2016) declared the Zika virus a global health emergency, foreseeing that four million people could become infected that year. The medical authorities highlighted the urgent need to find a global response to an infection that has been connected to serious brain anomalies in newborns. ${ }^{2}$ 
Public health issues, especially if linked to emergency situations, such as pandemics, are the target of extensive media attention and therefore arouse a great deal of interest in audiences (Lopes et al., 2012). News stories on diseases, outbreaks and epidemics are often given a sensationalist treatment and can encourage people to search for information and clarification-on symptoms, treatments, cases, deaths -in both traditional media and online settings. Alongside conventional newscasts, websites, blogs, social media are today important information sources and are often consulted with no filters as to the credibility of the sender or the quality of the message.

This chapter starts with a presumption that hospital organizations, due to the nature of their mission in society, are an ideal source of information on health. They therefore produce high-quality content on both general health topics and emergency public health issues, such as the Zika virus. According to a WHO survey, in 2015, health organizations in $81 \%$ of European Union Member States used social media to promote health messages integrated into public health campaigns, $74 \%$ to make general announcements on health topics, $65 \%$ to obtain feedback on their services, and, in roughly half of countries, to make emergency announcements. In this context, the hypothesis guiding this study will be that Portuguese hospitals follow the European trend, using Facebook, the social network with the greatest impact and prominence on the internet, to communicate and interact with their patients and followers on health topics in general and on the Zika virus in particular.

The chapter is split into two main sections: a literature review and empirical application. The literature review is presented in two parts. The first discusses online health communication, particularly the trends and challenges faced by hospital organizations when managing communication on social media. There is then a discussion of the internet's potential in building relationships between organizations and their publics, with special emphasis on Kent and Taylor's $(1984,2002)$ five dialogic principles model. The empirical part includes a reflection on the strategic potential of online communication in building relationships by studying the role of Facebook in hospital organizations' communication.

\section{Online health communication}

According to the Health Online Project (2013), organized by Pew Research Centre's Internet \& American Life Project, one in every three American adults make internet searches about medical issues on the internet. ${ }^{3}$ In Europe, the WHO eHealth (2007) survey, carried out in seven countries (including Portugal), showed that $71 \%$ of internet users use the internet to make searches about health (Andreassen et al., 2007). ${ }^{4}$ More recently, 
in 2015, a survey performed by the same organization indicated that citizens in $91 \%$ of Member States used social media to learn about health topics.

However, despite the high number of people who search for health topics, many are skeptical about messages and information available on websites about health. Several studies have demonstrated that individuals often question the quality of information shared online and the credibility of people involved in discussions on health forums (e.g. Craigie et al., 2002; Eastin, 2006; Griffiths \& Christensen, 2000). According to Cline and Haynes (2001), the information available online is often imprecise and misleading because of the lack of content monitoring and the absence of regulation. In fact, anyone can easily set up a website today and publish content on diseases. The excess and disorganization of online information, together illiteracy on health, i.e. a lack of skills to search for and select valid information, may even encourage risk behavior (Griffiths \& Christensen, 2000).

"Science and snake oil may not always look that different on the Net," claim Silberg et al. (1997, p. 1244). To counter the risks of disinformation, Cline and Haynes (2001) argue that medical organizations should take more proactive steps in the world of virtual communication to establish themselves as reliable, credible information sources on health matters. Some of the strategies that can help reduce consumers' health concerns include email exchanges between doctors and patients, publishing blogs containing questions and answers, and sending messages via mailing lists. These online strategies, while reaching a high number of publics, also enable interpersonal communication on health matters between doctors and patients, whether these are potential or actual.

In the study "A 10-year retrospective of research in new technologies for health communication," Suggs (2006) highlights that interactivity is the most important feature in keeping health consumers' attention in the digital world. In fact, it is not by chance that the health industry uses social media as an essential marketing tool. For hospital organizations, social media is an excellent resource for spreading advertising on their products and services, as well as to communicate their mission and institutional vision (Huang \& Dunbar, 2013). Facebook, in particular, due to its high number of followers, is a free tool that has commonly been used by hospitals to disseminate brand architecture (Medina et al., 2016) and increase its visibility (Coustasse \& Slack, 2013).

Several studies have been carried out on the use of social media by hospitals in national contexts, particularly in North America. Richter et al. (2014), for example, discovered that seven in ten hospitals use Facebook essentially to spread educational messages on health, to introduce the medical and technical 
team, and to share news stories on awards received by the hospital organization. Coustasse and Slack (2013) also describe the information most commonly inserted in hospital Facebook pages: stories about patients, experts' opinions (which are essentially medical and technical), details on what to expect during a procedure or specific examination and health tips. Sharing of photographs is indicated as the most common interactive tool on the profiles analyzed.

These and other studies highlight the fact that most hospitals do not actively interact with followers on their Facebook pages. When analyzing the Twitter profiles and Facebook pages of 172 North American hospitals, Huang and Dunbar (2013) discovered that the flow of information is primarily one-directional, and this is particularly evident on Twitter. In the European setting, a very recent comparative research project carried out in Spain concluded that although Spanish hospitals have an extensive online presence, especially by way of institutional websites, their presence on the three main social networks (Facebook, Twitter, and YouTube) is smaller than among North American hospitals (Martinez-Millana et al., 2017). Hospitals are therefore missing an opportunity to modernize customer care, obtain feedback on the quality of care given and build brand loyalty in online communities.

As is the case at any kind of organization, for social media communication strategies to be successful, it is important to reach a broad base of followers. The more visitors a Facebook page has, the more likes and posts it attracts, the more people will comment and recommend the hospital. Huang and Dinbar (2013) argue that the use of social media as a two-way communication channel is a much more effective way for hospitals to connect with their visitors. When the communication flow is predominantly in one direction, it means that social media is only seen as a channel the perpetuates one type of downward communication, ignoring horizontal communication between individuals, which makes it harder to create online communities. As Boyer (2011) highlights, hospitals' social media should be focused on patients:

It's dangerous-and inaccurate-to view social media as another way to broadcast one-way messages to the community. Marketers who see social media as a way to talk at, not with, their followers are not fully engaging them... The last thing patients want when following a hospital on social media is marketing (p. 36) [ ... ] Social media tools should not be used to simply broadcast messages about quality awards, surgical robots, and great doctors. Instead, focus on building honest and authentic conversations. (p. 38)

Rooted in a public relations approach, Kent and Taylor's (1998, 2002) dialogic theory, which is presented below, offers a solid base to counteract the marketing approach and further enhance analysis of the interactive nature of organizations in the social media context. 


\section{Dialogic communication on the web}

Organizations have increasingly adopted communication strategies that take social media into consideration. However, as Gonçalves and Elias (2013) stress, it is extremely important for organizations to use those new media in a considered, professional way, targeted at building dialogic relationships.

"The web has great potential as a channel of dialogic communication," state Kent and Taylor (1998, p. 331) in the article that pioneered the theme of dialogic communication in public relations studies. In the article, the authors highlight the importance of using specific web characteristics to create, adapt and change relations between organizations and their publics. More specifically, they propose five guiding principles for organizations' actions in web environments: (1) dialogic loop; (2) usefulness of information; (3) generation of return visits; (4) intuitiveness/ease of interface; and (5) conservation of visitors.

The dialogic loop principle deals with interactivity, i.e. feedback from the public to the organization and its response to the public, whether dealing with requests for information or solving problems. In other words, the potential for organizations to have closer, quicker and more personalized contact with their publics. For this principle to actually be applied, a trained team is fundamental. Perhaps for that very reason, organizations find it somewhat difficult to implement the dialogic loop, as demonstrated by Taylor and Kent (2004) in a study of the US Congress' websites and by Gonçalves and Serra (2015) in an analysis of the websites of Portuguese political parties.

The usefulness of information principle highlights the importance of valuable information being publicized on the web that meets stakeholders' information needs. If the public trusts the information made available by the organization, it can participate in the dialogue as an informed partner. Kent and Taylor (1998) claim that data on the organization and its history are valuable for all publics and that it should be reliable, relevant and consistent.

The third principle, generation of return visits, explores ways of creating a basis for long-lasting relationships and can be achieved using interactive strategies (e.g. forums, Q\&A, specialist publications, links). Diversity and keeping content updated encourages return visits and this is a fundamental condition for creating dialogic relationships. As Kent and Taylor explain, "visitors should not have to follow apparently 'random' links to find what a website's information contains and where the links take them" (1998, p. 329). That is why the fourth principle is so important, the principle of intuitiveness/ease of interface. Whatever the platform, the structure should be compatible with the design to let users use the site without 
encountering difficulties. It is essential for access to the information to be easy and intuitive, for the page to load quickly, and for the menus to be easy-to-use.

Finally, the principle of conservation of visitors indicates the need to keep platforms organized so visitors stay on the pages rather than leading them to external links. "It is important to include only interesting links and avoid advertising. An organization can only create a good relationship if its users visit its website often" (Gonçalves \& Elias, 2013, p. 137).

Kent and Taylor's theory on dialogic communication would later be enhanced by the authors when they added five fundamental characteristics: "mutuality, propinquity, empathy, risk, commitment" (Kent \& Taylor, 2002, p. 24). "Mutuality" refers to an orientation towards collaboration, in the spirit of mutual equality between an organization and its publics; "propinquity" (or proximity) relates to the spontaneity of interactions with publics; "empathy" regards the creation of a climate of trust and understanding; "risk" suggests a will to interact with individuals on their own terms, involving common relationship consequences in a dialogue; and "commitment" can be observed in an organization's degree of dedication to dialogue, interpreting and understanding interactions with the public (Kent \& Taylor, 2002).

According to the bibliographic review carried out by McAllister-Spooner (2009) and Augusto (2016), Kent and Taylor's dialogic principles have already been applied to a very wide range of organizations, with emphasis on research focusing on activist websites (Reber \& Kim, 2006; Seltzer \& Mitrook, 2007; Sommerfeldt et al., 2012; Taylor et al., 2001), organizations in the event sector (Taylor \& Kent, 2004), education institutions (Bo-seob et al., 2009; Lee \& Park, 2013; McAllister \& Taylor, 2007; McAllisterSpooner \& Kent, 2009; McAllister-Spooner, 2010), public sector companies (Waters et al, 2011), and not-for-profit organizations (Ingenhoff \& Koelling, 2009). Generally speaking, these studies reveal that websites fulfil some dialogic functions, namely ease of use, dissemination of useful information and conservation of visitors, but they rarely fulfil the dialogic function regarding the inclusion of resources to encourage repeat visits and user interaction (the dialogic loop). Nonetheless, by analyzing user perceptions as to the importance of the dialogic principles, McAllister-Spooner (2008) concluded that users view dialogic principles positively, demonstrating a negative attitude towards a lack of interactive dialogic resources that allow them to give feedback.

Initially foreseen to study institutional websites, Kent and Taylor's principles would quickly be applied, although less often, to other online platforms, such as blogs (Seltzer \& Mitrook, 2007), the Facebook pages of environmental groups (Bortree \& Seltzer, 2009) and university health 
centers (Waters et al, 2011), the Twitter accounts of the Fortune 500 (Rybalko \& Seltzer, 2010), and medical wikis (Hickerson \& Thompson, 2009). Once again, these studies also reflect organizations' difficulties in implementing the dialogic loop, whether due to an absence of public relations or marketing teams to monitor and quickly reply to questions sent to them by publics on online platforms, or due to the a lack of sensitivity in those teams or people at the organization in charge of using the web in a dialogic way.

Research already carried out regarding dialogic principles on online platforms indicate the relevance of continuing to further develop the study of dialogic strategies developed by different organizations. As already highlighted, the dialogic principles have been used especially in research on websites and in a less widespread way on social media. The exploratory study presented below is original because of the absence of studies on dialogic principles on social networks in general and in the field of hospital organizations in particular.

Three questions guide the study, framed by the theoretical reflection on the online communication of health organizations and the dialogic theory of public relations. The first research question is as follows:

Q1. To what extent do Portuguese hospitals apply the dialogic principles on their Facebook pages?

In Portugal, hospital organizations may be public, private or under public-private management, with resulting differences in institutional missions, visions and values. It was therefore considered relevant to add a research question to enable a comparative analysis of the data relating to application of the dialogic principles.

Q2. What differences are there in the application of dialogic principles to Facebook pages by public and private hospitals?

Finally, a third question was drawn up to guide the study regarding communication on the Zika theme that would make it possible to carry out a specific analysis on the usefulness of information principle during a public health emergency.

Q3. Did Portuguese hospitals use Facebook to notify and inform Portuguese citizens about the Zika outbreak?

\section{Method}

To understand how Portuguese hospitals incorporate the dialogic principles on Facebook (FB), a content analysis of the official pages of a sample of public and private hospitals was performed. ${ }^{5}$ To establish the sample, research was first carried out on how many public and private hospitals 
Table 1. Study sample.

\begin{tabular}{lclc}
\hline & Total & w/ FB & Sample* \\
\hline Private hospitals & 41 & 27 & 18 \\
$\%$ & & 65.85 & 43.90 \\
Public hospitals & 48 & 17 & 11 \\
$\%$ & & 35.41 & 22.91 \\
Total & 89 & 44 & 29 \\
$\%$ & & 49.43 & 32.58 \\
\hline
\end{tabular}

*With updated posts during the analysis period (15 January-28 February 2016).

exist in mainland Portugal by consulting National Health Service ${ }^{6}$ websites and the Portuguese Association of Private Hospitals. This consultation made it possible to identify a total of 89 hospitals in mainland Portugal48 public hospitals and 41 private hospitals. ${ }^{8}$ Afterwards, it was observed how many of these hospitals have an official page on FB and, of these, how many made posts in January and February 2016. The analysis period was selected because it corresponded to the period of the Zika outbreak in Portugal. It would be expected, at this time, that hospitals, following statements released by the Directorate-General for Health (DGS), would share information about Zika. ${ }^{9}$

As shown in Table 1, the sample included 29 hospitals: 18 private and 11 public.

In the content analysis of the FB pages of these 29 hospitals, a codification scheme was adopted based on dialogic communication literature (Kent \& Taylor, 1998; Taylor et al., 2001; Kent et al., 2003). The items that measure Taylor et al.'s (2001) dialogic strategies-ease of interface, usefulness of information, conservation of visitors, generation of return visits and dialogic loop-were modified for application to the FB social network context and codified as "present" or "not present" throughout the analysis.

Additional data was also found, through the content analysis, on each of the hospitals, including a description of the profile, number of "friends", "fans" or "members", type of profile image/photo, information on contact details and presentation of the organization (institutional vs. informal).

\section{Discussion of the results}

The sample of hospitals with an up-to-date presence on Facebook (FB) at the beginning of 2016 (January-February) was 29 hospitals (32.6\%) out of a total of 89,11 public (12.4\%) and 18 private $(20.2 \%)$. The hospital profiles analyzed had, on average, 970 likes on 1 February 2016. In the case of public hospitals, the number of likes varied between 1,794 and 10,133, and in the case of private hospitals, between 951 and 168,288.

The first research question's aim was to determine how Portuguese hospitals apply the dialogic principles on their FB pages and the second was to ascertain whether that application varied between the public and private 
Table 2. Presence of dialogic features on hospital FB pages.

\begin{tabular}{|c|c|c|c|}
\hline Analysis items & $\begin{array}{c}\text { Total } \\
(n=29)\end{array}$ & $\begin{array}{l}\text { Public hospitals } \\
\qquad(n=11)\end{array}$ & $\begin{array}{l}\text { Private hospitals } \\
\quad(n=18) \\
\end{array}$ \\
\hline \multicolumn{4}{|l|}{ Ease of interface } \\
\hline Images & $29(100 \%)$ & $11(100 \%)$ & $18(100 \%)$ \\
\hline Videos & $21(72 \%)$ & $07(64 \%)$ & $14(78 \%)$ \\
\hline Pinned posts & $06(21 \%)$ & $04(36 \%)$ & $02(11 \%)$ \\
\hline Use of \#hashtags & $05(17 \%)$ & $01(18 \%)$ & $03(17 \%)$ \\
\hline \multicolumn{4}{|l|}{ Usefulness of information } \\
\hline About the organization (mission/vision/goals) & $22(76 \%)$ & $08(73 \%)$ & $14(78 \%)$ \\
\hline Contact information (e-mail/telephone/address) & $28(97 \%)$ & $10(91 \%)$ & $18(100 \%)$ \\
\hline Posts about hospital news/events & $26(89 \%)$ & $11(100 \%)$ & $15(83 \%)$ \\
\hline Posts about commemorative dates & $20(69 \%)$ & $05(45 \%)$ & $15(83 \%)$ \\
\hline Posts about diseases & $12(41 \%)$ & $02(18 \%)$ & $10(56 \%)$ \\
\hline Posts about Zika & $03(10 \%)$ & $02(18 \%)$ & $01(6 \%)$ \\
\hline \multicolumn{4}{|l|}{ Dialogic link } \\
\hline Email address & $27(93 \%)$ & $09(82 \%)$ & $18(100 \%)$ \\
\hline Allows answers to posts & $29(100 \%)$ & $11(100 \%)$ & $18(100 \%)$ \\
\hline Allows rating & $24(83 \%)$ & $10(91 \%)$ & $14(78 \%)$ \\
\hline Allows private messages to be sent & $26(89 \%)$ & 09 (82\%) & 17 (94\%) \\
\hline Replies to comments & $10(35 \%)$ & $02(18 \%)$ & $08(44 \%)$ \\
\hline Replies to criticism & $04(14 \%)$ & 0 & $04(22 \%)$ \\
\hline \multicolumn{4}{|l|}{ Generation of return visits } \\
\hline Explicit appeal to come back to the page & $01(3 \%)$ & 0 & $01(6 \%)$ \\
\hline Daily posts & $01(3 \%)$ & 0 & $01(6 \%)$ \\
\hline Call for action button & $27(93 \%)$ & $09(82 \%)$ & $18(100 \%)$ \\
\hline Scheduling of events & $14(48 \%)$ & $06(55 \%)$ & $08(44 \%)$ \\
\hline Possibility to share & $29(100 \%)$ & $11(100 \%)$ & $18(100 \%)$ \\
\hline Possibility to receive notifications & $29(100 \%)$ & $11(100 \%)$ & $18(100 \%)$ \\
\hline Allows tagging in photos & $05(17 \%)$ & $03(27 \%)$ & $02(11 \%)$ \\
\hline Likes on comments & $13(45 \%)$ & $03(27 \%)$ & $10(56 \%)$ \\
\hline \multicolumn{4}{|l|}{ Conservation of visitors } \\
\hline Link to the hospital website & $29(100 \%)$ & $11(100 \%)$ & $18(100 \%)$ \\
\hline Appealing titles & $28(97 \%)$ & $11(100 \%)$ & $17(94 \%)$ \\
\hline Instant replies to comments & $07(24 \%)$ & $02(18 \%)$ & $05(28 \%)$ \\
\hline
\end{tabular}

sectors. As can be observed in the analysis of Table 2, hospitals generally incorporate the dialogic principles to some extent on their FB profiles.

In terms of the ease of interface principle, all the pages analyzed use images in their posts and $72 \%$ include videos as a way of adding information. However, less than a quarter $(21 \%)$ uses pinned posts, which are an important FB function, since it is the first information that can be seen when visiting a page. Among public hospitals, 36\% use this feature, while only $11 \%$ of private hospitals do so. Hashtags, which are an easy way to catalogue and group together information, are also underused, found on only $17 \%$ of the total number of FB pages analyzed.

When analyzing the dialogic principles regarding usefulness of information, it was found that all hospitals prominently display their name and/or logo. Roughly $76 \%$ of hospitals have a mission statement on their FB profile, all private hospitals provide their contact details (whether e-mail, telephone and/or address), and only one of the public hospitals does not provide that information. The most common of the different post categories analyzed (on hospital news/events, commemorative dates, diseases, 
Zika) was "hospital news/events" (found on $100 \%$ of public hospital profiles and $83 \%$ of private hospital profiles). Posts about diseases are present on roughly half of the FB pages analyzed (41\%), but are visibly less common in the case of public hospitals (18\%).

The third research question led to an analysis of the usefulness of information principle in the specific case of the Zika virus. The following result is clear: the presence of information about Zika is limited on the FB pages analyzed. More specifically, only two public hospitals (18\%) and one private hospital (6\%) shared posts on the topic during the period analyzed and did not give them any special emphasis.

Some of the items that characterize the dialogic loop principle offer the lowest content analysis scores. All the hospitals studied allow visitors to comment on their posts, however, only $18 \%$ of public hospitals and $44 \%$ of private hospitals reply to those comments. As for private messages, $82 \%$ of public hospitals have the feature activated, as well as providing an e-mail address. Among the private hospitals, all provide a contact e-mail address and $94 \%$ allow private messages to be sent. Ratings, an FB feature, can be given on $91 \%$ of public hospital pages and $78 \%$ of private hospital pages. However, it is noteworthy that none of the public hospitals reply to internet users' criticisms and only $22 \%$ of private hospitals provide any response.

To keep visitors on the page, the most common strategy is a link to the hospital website, information which is found on all the pages analyzed. Immediate replies to comments is also an effective way of keeping visitors on a specific FB profile. Nevertheless, only roughly $24 \%$ of hospitals appear to do so; more specifically, $18 \%$ of public hospitals and $28 \%$ of private hospitals.

Finally, return visits to the Facebook profile are encouraged via the possibility of activating notifications, found on all hospitals' pages, and also the presence of "call to action" buttons on 93\% of hospital pages. This button is an FB features that makes it possible to highlight a certain contact.

FB also provides a virtual calendar where all events can be shown, a simple feature that $45 \%$ of public hospitals and $56 \%$ private hospitals choose not to use. Tagging in photos is not allowed by $73 \%$ of public hospitals and by $89 \%$ of private hospitals. The possibility of "liking" visitor comments, a tool that encourages return visits to the post, is an option chosen by only $27 \%$ of public hospitals and $56 \%$ of private hospitals. An explicit call to visit the page again was only found on the page of one private hospital.

In short, overall all the dialogic principles are implemented on Portuguese hospitals' FB pages, although there are variations between them. The content analysis shows that private hospitals manage to apply all the principles better, particularly, although with limitations, the dialogic loop and conservation of visitors principles. It can be concluded that they are making better use of FB features to inform and interact with their publics, 
although they did not, like public hospitals, give any emphasis to information pertaining to the Zika virus. Of a total of 29 hospitals, only three hospitals, one private and two public, published posts on Zika.

\section{Concluding notes}

The results of this study show that hospital organizations do not use all of FB's potential to create continued, positive relationships with their patients and followers. Although hospitals' presence on social media demonstrates a concern with maintaining contact with real and potential patients, these types of organizations have not yet been able to create continued dialogue and interaction, key characteristics of social platforms. Organizations that choose not to reply to comments and not to interact in the digital space discourage visitors from maintaining online relations with them. A more careful application of Kent and Taylor's dialogic principles may help hospitals position themselves as credible sources of health information by informing, in good time, about themes of alerts in public health, as in the case of the Zika virus.

The ultimate goal of any online communication strategy is to build virtual communities. But doing so requires a team of professionals available to keep the website updated and interactive. Simply setting up an FB profile is not enough to gain a large number of followers. Time and, above all, interaction are needed to reach higher levels of engagement (likes, shares, comments, posts, etc.). Applying the dialogic principles may contribute to the organic growth of an online community. Furthermore, to achieve high flows of interactivity, it is important to understand followers' information needs to provide that information and ensure it is of high quality.

Frequent updates and co-shared posts with followers on the social network is the most basic and suitable way to build relationships in an online community. Both public relations and marketing professionals may be tempted to simply publicize content, choosing a type of one-way communication. But, when observing the most interactive hospital FB profiles, they are the ones found to have the most followers. For any strategy to be successful, hospital organization should have a well-defined social media policy that is followed by the members of staff involved, whether they are communication managers or health care workers, such as doctors, nurses or others.

Future research on communication among health care organizations in online environments may continue to focus on the agent's perspective, i.e. the departments responsible for hospitals' communication. On the one hand, it would be relevant to understand whether or not there is a national policy on the use of social media in health care and what communication 
strategies guide it. According to the 2006 WHO report, only seven countries in the European region (16\%) report the existence of a national strategy or policy on the use of social media by public organizations and, of these, only one country (the United Kingdom) specifically mentions the use of social media in the health care field. On the other hand, it will also be important to understand, at hospital level, which departments and, more specifically, which staff members are responsible for communication and what the communication policy underlying communication management is, both in terms of integration into the national policy for social media use in health care-if applicable-and in terms of management and integration in the hospital's overall communication strategy.

The study's main limitation demonstrated related to the perspective of the analysis chosen, which is heavily focused on the sender-in this specific case, the Facebook profiles of hospital organizations. Future research should broaden the analysis to include the perceptions of organizations' online followers and the characteristics of those publics. Understanding what health consumers' opinions are, whether they are hospitals' actual or potential patients, family members, journalists, health care workers or others, on the interaction made possible by social media will create a better, deeper understanding of how relationships are built in web environments.

\section{Notes}

1. The three DGS statements were issued on 15 January, 28 January, and 16 February 2016 and are available in full on the Directorate-General for Health website: https://www.dgs.pt/paginas-de-sistema/saude-de-a-a-z/zika.aspx [accessed on 22 April 2016]

2. WHO statement available at: http://www.who.int/mediacentre/news/statements/2016/ 1st-emergency-committee-zika/en/ [accessed on 22 April 2016].

3. Available at http://www.pewinternet.org/2013/01/15/health-online-2013/ [accessed on 26 April 2016].

4. As well as Portugal, the survey included samples representing the populations of Norway, Denmark, Germany, Greece, Poland and Latvia (Andreassen et al., 2007).

5. I would like to think Vanessa Santos, holder of a Master's Degree in Strategic Communication from UBI, for her help in collecting the online data.

6. https://servicos.min-saude.pt/utente/HealthProviders, accessed on 20 April 2016

7. http://www.aphp-pt.org/index.php/associados/membros, accessed on 22 April 2016

8. Hospitals in Portugal can be public, private, or under public-private management. To help with the discussion of the results, the data was split into 2 categories: public hospitals and private hospitals, without specifying which are under publicprivate management.

9. The DGS released three statements (15 and 28 January and 16 February 2016) which are available in full on the Directorate-General for Health website: https://www.dgs.pt/ paginas-de-sistema/saude-de-a-a-z/zika.aspx [accessed on 22 April 2016] 


\section{Disclosure statement}

No potential conflict of interest was reported by the author(s).

\section{References}

Andreassen, H. K., Bujnowska-Fedak, M. M., Chronaki, C. E., Dumitru, R. C., Pudule, I., Santana, S., Voss, H., \& Wynn, R. (2007). European citizens use of e-health services: A study of seven countries. BMC Public Health, 7(53), 53. https://doi.org/10.1186/14712458-7-53

Augusto, L. (2016). Relações públicas e turismo: Media digitais e formação da imagem de destino. Livros Labcom.

Bortree, D. S., \& Seltzer, T. (2009). Dialogic strategies and outcomes: An analysis of environmental advocacy groups' Facebook profiles. Public Relations Review, 35(3), 317-319. https://doi.org/10.1016/j.pubrev.2009.05.002

Bo-Seob, A., Hyun-Ji, D., \& Sang-Pil, H. (2009). Effects of dialogic functions of websites on organization public relationships. Korea Journalism Review, 4(2), 61-85.

Boyer, C. (2011). Social media for healthcare makes sense. Frontiers of Health Services Management, 28(2), 35-40.

Cline, R. J. W., \& Haynes, K. M. (2001). Consumer health information seeking on the internet: The state of the art. Health Education Research, 16(6), 671-692. https://doi.org/ 10.1093/her/16.6.671

Coustasse, A., \& Slack, C. (2013). Potential benefits of using Facebook in the healthcare industry: A literature review. Insights to A Changing World Journal, 2013(1), 41-52.

Craigie, M., Loader, B., Burrows, R., \& Muncer, S. (2002). Reliability of health information on the Internet: An examination of experts' ratings. Journal of Medical Internet Research, 4(1), e2. https://doi.org/10.2196/jmir.4.1.e2

Eastin, M. S. (2006). Credibility assessments of online health information: The effects of source expertise and knowledge of content. Journal of Computer-Mediated Communication, 6(4), https://doi.org/10.1111/j.1083-6101.2001.tb00126.x

Gonçalves, G., \& Elias, H. (2013). Comunicação estratégica. Um jogo de relações e aplicações. In A. Fidalgo \& J. Canavilhas (Org.), Comunicação digital. 10 anos de investigação (pp. 135-150). MinervaCoimbra.

Gonçalves, G., \& Serra, P.J. (2015). Online relationship management and digital participation in the political sphere: A communicative myth? In Ana Duarte Melo, Ian Somerville, \& Gisela Gonçalves (Org.), Organisational and strategic communication research: European perspectives II (pp. 9-26). CECS.

Griffiths, K. M., \& Christensen, H. (2000). Quality of web based information on treatment of depression: Cross sectional survey. BMJ (Clinical Research ed.), 321(7275), 1511-1515. https://doi.org/10.1136/bmj.321.7275.1511

Hickerson, C. A., \& Thompson, S. R. (2009). Dialogue through wikis: A pilot exploration of dialogic public relations and wiki websites. Prism, 6 (1), 1-11.

Huang, E. e., \& Dunbar, C. (2013). Connecting to patients via social media: A hype or a reality? Journal of Medical Marketing: Device, Diagnostic and Pharmaceutical Marketing, 13(1), 14-23. https://doi.org/10.1177/1745790413477647

Ingenhoff, D., \& Koelling, A. M. (2009). The potential of web sites as a relationship building tool for charitable fundraising NPOs. Public Relations Review, 35(1), 66-73. https:// doi.org/10.1016/j.pubrev.2008.09.023 
Kent, M., \& Taylor, M. (1998). Building dialogic relationships through the world wide web. Public Relations Review, 24(3), 321-334. https://doi.org/10.1016/S0363-8111(99)80143-X

Kent, M. L., \& Taylor, M. (2002). Toward a dialogic theory of public relations. Public Relations Review, 28(1), 21-37. https://doi.org/10.1016/S0363-8111(02)00108-X

Kent, M. L., Taylor, M., \& White, W. J. (2003). The relationship between Web site design and organizational responsiveness to stakeholders. Public Relations Review, 29(1), 63-77. https://doi.org/10.1016/S0363-8111(02)00194-7

Lee, H., \& Park, H. (2013). Testing the impact of message interactivity on relationship management and organizational reputation. Journal of Public Relations Research, 25(2), 188-206. https://doi.org/10.1080/1062726X.2013.739103

Lopes, F., Ruão, T., Marinho, S., \& Araújo, R. (2012). A saúde em notícia entre 2008 e 2010: Retratos do que a imprensa portuguesa mostrou, Comunicação $e$ Sociedade, [volume especial Mediatização Jornalística do Campo daSaúde], 129-170. doi: 10.17231/comsoc.23(2012).1361

Martinez-Millana, A., Fernandez-Llatas, C., Bilbao, I. B., Salcedo, M. T., Salcedo, V. T., Bilbao, I., \& Traver Salcedo, V. (2017). Evaluating the social media performance of hospitals in Spain: A longitudinal and comparative study. Journal of Medical Internet Research, 19(5), e181. https://doi.org/10.2196/jmir.6763

McAllister-Spooner, S. M. (2008). User perceptions of dialogic public relations tactics via the Internet. Public Relations Journal, 2(1), 1-18.

McAllister-Spooner, S. M. (2009). Fulfilling the dialogic promise: A ten-year reflective survey on dialogic Internet principles. Public Relations Review, 35(3), 320-322. https://doi. org/10.1016/j.pubrev.2009.03.008

McAllister-Spooner, S. M. (2010). Whose site is it anyway? Expectations of college Web sites. Public Relations Journal, 4(2). https://prjournal.instituteforpr.org/wp-content/ uploads/Whose-Site-Is-It-1.pdf.

McAllister-Spooner, S. M., \& Kent, M. L. (2009). Dialogic public relations and resource dependency: New Jersey community colleges as models for web site effectiveness. Atlantic Journal of Communication, 17(4), 220-239. https://doi.org/10.1080/ 15456870903210113

McAllister, S. M., \& Taylor, M. (2007). Community college websites as tools for fostering dialogue. Public Relations Review, 33(2), 230-232. https://doi.org/10.1016/j.pubrev.2007. 02.017

Medina, P., Buil, P., \& Heath, R. L. (2016). Establishing and demonstrating US hospital brands through Facebook. Observatorio, 10(3), 020. https://doi.org/10.15847/ obsOBS1032016912

Reber, B. H., \& Kim, J. K. (2006). How activist groups use websites in media relations: Evaluating online press rooms. Journal of Public Relations Research, 18(4), 313-333. https://doi.org/10.1207/s1532754xjprr1804_2

Richter, J. P., Muhlestein, D. B., \& Wilks, C. A. (2014). Social media: How hospitals use it, and opportunities for future use. Journal of Healthcare Management/American College of Healthcare Executives, 59(6), 447-460.

Rybalko, S., \& Seltzer, T. (2010). Dialogic communication in 140 characters or less: How Fortune 500 companies engage stakeholders using Twitter. Public Relations Review, 36(4), 336-341. https://doi.org/10.1016/j.pubrev.2010.08.004

Seltzer, T., \& Mitrook, M. A. (2007). The dialogic potential of weblogs in relationship building. Public Relations Review, 33(2), 227-229. https://doi.org/10.1016/j.pubrev.2007. 02.011 
Silberg, W. M., Lundberg, G. D., \& Musaccio, R. A. (1997). Assessing, controlling, and assuring the quality of medical information on the Internet: Caveat lector et viewor-let the reader and viewer beware. JAMA, 277(15), 1244-1245. https://doi.org/10.1001/jama. 1997.03540390074039

Sommerfeldt, E. J., Kent, M. L., \& Taylor, M. (2012). Activist practitioner perspectives of website public relations: Why aren't activist websites fulfilling the dialogic promise? Public Relations Review, 38(2), 303-312. https://doi.org/10.1016/j.pubrev.2012.01.001

Suggs, L. S. (2006). A 10-year retrospective of research in new technologies for health Communication. Journal of Health Communication, 11(1), 61-74. https://doi.org/10. 1080/10810730500461083

Taylor, M., \& Kent, M. L. (2004). Congressional web sites and their potential for public dialogue. Atlantic Journal of Communication, 12(2), 59-76. https://doi.org/10.1207/ s15456889ajc1202_1

Taylor, M., Kent, M. L., \& White, W. J. (2001). How activist organizations are using the Internet to build relationships. Public Relations Review, 27(3), 263-284. https://doi.org/ 10.1016/S0363-8111(01)00086-8

Waters, R. D., Canfield, R. R., Foster, J. M., \& Hardy, E. E. (2011). Applying the dialogic theory to social networking sites. Journal of Social Marketing, 1(3), 211-227. https://doi. org/10.1108/20426761111170713

WHO. (2016). From innovation to implementation. eHealth in the WHO European Region. http://www.euro.who.int/en/health-topics/Health-systems/e-health (accessed June 15, 2017). 